\title{
Universalisme en partikularisme vandag
}

HG van der Westhiuzen

Hervormde Teologiese Opleiding

\begin{abstract}
Universalism and particularism today

Today we are heirs to a great variety of conceptions in particularism and universalism. It usually represents a view on world and life that is reflected mutually on domains of church and state. Universalism especially increases in seriousness and extent as is to be noticed in the ecumenical theology and the foundation in the United Nations and the so-called human rights. The proper conception of particularism however, serves a proper conception of universalism.
\end{abstract}

\section{INLEIDENDE PERSPEKTIEWE}

Dit sou te uitgebreid wees om die studie van hierdie tema vanuit die OuTestamentiese, die Nuwe-Testamentiese en die historiese fasette ook in hierdie kort artikel te inkorporeer. Genoemde drie fasette is egter noodsaaklike agtergrond waarteen die verskynsel van universalisme en partikularisme in die staatkundige en kerklike wêreld van vandag van nader besien moet word. Beide begrippe verteenwoordig uiteenlopende lewens- en wèreldbeskouings. Elke begrip verteenwoordig ook verskillende lewens- en wêreldbeskouings.

Vir die huidige aanpak van die probleem van hierdie botsende lewens- en wêreldbeskouings, sal nie verder op die verskeidenheid as sodanig van elke begrip se lewens- en wêreldbeskouing ingegaan word nie. Daar sal eerder oor die algemene universalistiese en die partikularistiese lewensbenadering in kerk en staat veral wat die Republiek van Suid-Afrika betref - nagedink word.

'n Ander perspektief wat ook in die gesigsveld kom by die behandeling van hierdie tema, is die perspektief uit die Sending- en Godsdienswetenskap. Wie Godsdienswetenskap sê, veral uit die historiese oorsprong van die vak in die Aufklärung, sê in 'n sekere sin ook universalisme. PJ van der Merwe sê hiervan (Eybers, König \& Stoop 1978: 253): 'Daar is gehøop dat Godsdienswetenskap die 
ryke skat van kennis, wysheid en waarheid in hierdie godsdienste sou ontgin en so die geleerdes van die Aufklärung in staat sou stel om die kerk en teologie na die kroon te steek.' Wie Sendingwetenskap sê, veral uit die historiese of klassieke en eg Bybelse oorsprong, sê voor-die-hand-liggend meteens ook partikularisme. Deel van die probleem is juis dat hierdie partikularisme waarvan die Sendingwetenskap nog altyd uitgegaan het, ook in die Sendingwetenskap vandag in sekere gevalle gepoog word om dit uit te fasseer.

Omdat prof dr FJ van Zyl, emeritus van die Departement Godsdiens- en Sendingwetenskap (Afdeling A) aan die Universiteit van Pretoria, vanjaar, 1989, die sy vyftigste jaar as bedienaar van die Woord herdenk, wil skrywer as een van sy heel eerste studente in 1960 en sy eerste doktoraalstudent wat die volledige studie onder hom begin en in 1969 afgehandel het, hierdie artikel met dankbetuiging en goeie wense aan hom opdra.

Soos tot nou toe in die inleiding gedoen is, is die algemene gebruik van die begrippe partikularisme en universalisme redelik ongedefinieerd. Leksikalies beteken partikularisme: 'Die stel van eiebelang bo die algemene belang' (HAT 1979). Universalisme het 'n bietjie duideliker omlynde betekenis: '1 (teol) Geloof aan die algemeenheid van die genade van God. 2 Alomvattendheid' (HAT 1979).

Vir ons doel sal beide begrippe anvanklik in die algemeen as verskillende en teenoormekaarstaande lewens- en wêreldbeskouings benader word. In hierdie geval is die betrokke lewens- en wêreldbeskouings religieus gefundeer en samelewing- of staatkundig gerig.

Die uitstaande probleem rondom hierdie begrippe la in hulle teenoorgesteldheid, hulle botsende betekenisse en konflikskeppende uitwerking. Die een is die teenhanger van die ander. Myns insiens lê die oplossing van die probleem egter juis in die feit dat die een die anderkant van die ander is. Om dit tot 'n standpunt te konsentreer, moet die kombinasie van universalisme en partikularisme as teenhangers agtergrondshalwe ontleed word.

Die religieuse humanistiese en politieke hantering van universalisme word wat die historiese konteks betref in hierdie artikel minder geaksentueer as die Bybelse konteks.

\section{BENADERINGS}

Daar is basies twee universalistiese benaderings - 'n gerekonstrueerde en ' $n$ gerekonsilieerde. Die gerekonstrueerde wissel van 'n volkome gesekulariseerde evolusionêre eskatologie tot 'n wonderbaarlike ewigheidsduplikaat van die geskiedenis. Die gerekonsilieerde het ook wisselende verwagtings van 'n universele 
produk weens een of ander versoeningsopvatting.

Eerstens is daar die beskouing dat alle dinge, alle mense, alles in 'n apokatastasis, 'n wederoprigting of ' $n$ wederherstel vir ewig gerealiseer sal word. Die ekstreme standpunt in hierdie verband is die van Origines dat nie net alle mense nie maar ook die duiwels behoue sal bly (Van Genderen 1961: s v universalisme). Vergelyk egter noukeurig Matteus 19: 26; Handelinge 3: 21; Romeine 8: 21; Kolossense 1: 20 en Openbaring 21: 5 (Van der Westhuizen 1986a: 158).

'n Tweede voorbeeld van 'n beskouing wat universalisties neig, is die gedagte wat ook in die Rooms Katolieke Kerk figureer van 'n vagevuur. Hoewel die uitvee van sonde en die uitboet van tydelike straf in dié reinigingsvuur in teorie beperk is tot Rooms-Katolieke - extra ecclesiam (dws die Rooms-Katolieke Kerk) nulla salus est - is hier in prinsiep tog 'n universalisme in opgesluit. Daar kan offers, geldbydraes, goeie werke en gebede ten gunste van twyfelagtige gevalle gedoen word.

In wese dieselfde gedagte lê ook in 'n nog ouer opvatting as dié van die Rooms Katolieke. Die Jode se opvatting het hulle weliswaar weer net tot die biologiese Israel beperk. Israel is die roos van God terwyl die ander volke die dorings en die distels is. Israeliete wat darem nie te ergerlik geleef het nie, kan na die dood 'im purgatorium einen Läutenungsprozess durchlaufen, bevor sie ein Anrecht auf den künftigen Aeon erweben. Nach Akiba dauert der Aufenthalt im Fegefeuer 12 Monate' (Meyer 1942).

'n Derde vorm van 'n gedagte wat universalisties neig, hoewel ietwat anders as met die geval van die aangehaalde Rooms Katolieke en die Rabbynse voorbeeld wat met 'n universalisme in eie kring opereer, is die standpunt dat baie mense ná die dood 'n kans tot bekering sal kry.

As voorbeeld van hierdie universalistiese kans-opvatting kan die sogenaamde Worldwide Church of God genoem word. Die lektuur van hierdie denominasie word inderdaad feitlik wêreldwyd in vele tale versprei. Die leserskring van byvoorbeeld The Plain Truth, 'n maandblad, tel oor die agt miljoen.

Die universalistiese kans-opvatting van hierdie veldverowerende beweging word in hoofsake op 'n soort logika eerder as op 'n teologiese diepgang gefundeer. In kort kom die logiese redenasie daarop neer dat daar veel meer mense op aarde was en is en sal wees wat nooit van Christus gehoor het nie, as diegene wat wel die verkondiging van Christus as Verlosser verneem. Die meerderheid en in elk geval 'n massa mense kry nie 'n kans om in Christus te glo nie. Dít is tog onbillik. Voeg daarby nog dat God 'n God van liefde is, dan raak dit onmoontlik om te aanvaar dat billikheid en liefde s 6 kan funksioneer dat menigtes van mense sonder 'n kans om 
daaruit te kom, verdoemenis toe gaan. Dus die Bybel moet ' $n$ opening laat sodat elke mens minstens ' $n$ kans op redding mag kry.

Die beweging redeneer dan dat elkeen wat in hierdie lewe van Christus verneem en so 'n kans op verlossing kry, moet kies en finaal besluit. Só 'n persoon kry nie in ' $n$ ander bedeling 'n tweede kans nie. Maar diegene wat nooit in hierdie lewe 'n kans ontvang het nie, ontvang die geleentheid, die eerste geleentheid, by die opstanding.

Die moontlikheid hiervan word volgens hierdie beweging onder andere in Matteus 11: 22 gesuggereer waar Jesus sê dat dit in Tirus en Sidon op die oordeelsdag verdraagliker sal wees as vir die selfregverdige Jode.

In other words, Jesus is clearly indicating a coming time of judgment when PAGAN city-states like Tyre and Sidon may be saved. Again, Jesus told the men of nearby Capernaum that even the depraved inhabitans of Sodom would have repented if they had heard the truth he was now preaching (verses 23-24)! (Meredith 1986: 7).

Hierdie ná-wêreldse kans word glo in Openbaring 20: 11 en 12 genoem:

Here is the time when all those who have never really understood are resurrected, the 'books' of the Bible are opened to their understanding, and during this probable 100-year period (see Isaiah 65: 1725 , especially verse 20 ) they are tried, tested and 'judged' as to whether and how deeply they will surrender to God's Word and to his will in their lives .... The Bible indicates that the vast magnity will finally accept the true Christ and obey their Creator (Meredith 1986: $8,9)$.

Dat die huidige bedeling die enigste geleentheid sou wees waarop die mens 'n kans tot verlossing kry, word soos volg verwerp:

A primary scripture they use for this purpose is 2 Corinthians 6: 2: 'For he saith, $I$ have heard thee in a time accepted, and in the day of salvation have I succoured thee: behold, now is the accepted time; behold, now is the day of salvation? The truth is that virtually all Greek scholars know and acknowledge that the text should be translated ' $a$ day of salvation' in both instances, not 'the day' - as though God's time was limited. Paul is directly quoting from Isaiah 49: 8 
where both the original Hebrew and the English translations read ' $a$ day of salvation (Meredith 1986: 5)!

'n Woord soos Hebreërs 9: 27 word egter in hierdie argument buite rekening gelaat: 'n Mens is bestem om net een maal te sterf, en daarna kom die oordeel.

'n Vierde vorm van universalisme wat ook soos die Roomse en Rabbynse 'n universalisme in eie kring is, is die sogenaamde gemeenskapsteologieë, byvoorbeeld die Swart Teologie en die Wit Teologie.

Die Swart Teologie vind sy identiteit in die konteks van die ekumeniese en sosialistiese teologieë. Alhoewel die tendens by hierdie teologie is om die verdruktes en/of sogenaamde verdruktes as die kinders van God te bestempel aan wie die aarde behoort, is dit wesenlik ' $n$ verideologiseerde teologie en daarmee ' $n$ gesekulariseerde eskatologie. Vir sover daar dus van 'n universalisme hier sprake moet wees, is dit 'n hiernoumaalse universalisme. Die breër opset van hierdie universalisme sal later nog aangesny word.

Die so te noemde Wit Teologie is ook 'n rasmatige teologie wat 'n universalisme in eie kring voorstaan. In kort is daar volgens hierdie opvatting twee soorte mense - die kinders van God en die kinders van die bose. Eersgenoemdes is die Blankes en laasgenoemde die Nie-Blankes (Swart sj: 10). Omdat God via Adam, Abraham, Sinai en so meer 'n verbond met Israel (die Blankes) aangegaan het en omdat God se beloftes aan Israel nooit verander nie, gaan die Blankes nie verlore nie. 'Net Israel sal glo en gered word' (Swart sj: 19). Sending na Nie-Blankes sou op 'n misverstand berus. Vir sover die apostels self gemeen het hulle verkondig die evangelie aan nie-Israeliete, het hulle ook onder 'n misverstand verkeer. 'Selfs die Apostels het gedink dat hulle die evangelie aan die werklike heidene verkondig het, terwyl hulle hierdie evangelie aan die verlore 10 stamme van Israel in die verstrooiing en aan Israel in die verborgenheid verkondig het' (Swart sj: 39). Indien die hele sendingprojek van die kerk na Nie-Blankes nie as 'n dwaasheid afgemaak word nie, word die sending slegs as 'n noodsaaklike futiele oefening in wreedheid beskou: 'Die heidene (nie Israelse volke) daarenteen moet ook die evangelie hoor sodat hulle veroordeel kan word' (Swart sj: 19). Aan hierdie hele aweregse visie oor Israel is elders aandag gegee (Van der Westhuizen 1984; Van der Westhuizen 1989 ter perse).

\section{VARIASIES}

In die algemeen kom die gedagte binne en buite die Christendom van 'n almalinsluitende versoening en verlossing of saligheid in 'n verskeidenheid van variasies 
voor. In die charismatiese bewegings lê die moontlikheid van 'n eenheid tussen Roomses, Protestante, Ortodokse en selfs nie-Christene vir sover daar met die verbygaan van leerstellighede deelname plaasvind in gemeenskaplike ervaring. In hierdie kringe word ook beweer dat God met alle mense verder gaan totdat Hy sy doel van: God alles in almal (1 Kor 15: 28), bereik het (vgl Van der Westhuizen 1983: 39).

Oosterse godsdienste wat klem op meditasie lè, filosofieë wat klem op holisme lê en politiek wat die klem op die humanisme lê, is almal fabrieke om een of ander produk van universalistiese strekking te produseer.

So is daar byvoorbeeld die sogenaamde transendente meditasie waardeur 'n mens bo sy eie gedagtes en individuele bewussyn sou uitstyg tot 'n bewussyn van die Self, die Suiwer Bewussyn of God. Dit is 'n uitstyg bokant die ek na 'n sogenaamde kosmiese bewussyn. Aangesien dit maar verband hou met ander Oosterse universalistiese tendense soos jnana, bhakti, karma, raja yoga en so meer, word me! transendente meditasie gepoog om dit 'n Westerse kleed te gee met die beskrywing daarvan as kreatiewe intelligensie. Hierdie kreatiewe intelligensie program beoog 'n wêreldregering van volkome geluk, vrede, gesondheid, ordelikheid en so meer. Aangesien dit die organisasie van die ewige waarheid wat oral teenwoordig is, sal wees, is die diepste grond van hierdie ideologie, wat ook reeds sy miljoene tel, 'n hiernoumaalse eindbestemming (Getrouw sj: 860, 861).

\section{SINKRETISME}

Veral in die dampkring van die ekumenisme van ons dag, leef 'n gelykmakende universalisme waarna ondersoek gedoen moet word. Van sy oudste historiese wortels is die verskynsel van sinkretisme wat in 'n sekere mate 'n natuurlike verskynsel in die godsdienstige wêreld van die mensdom is. 'In die geskiedenis van die godsdiens lê sinkretisme altyd net onder die oppervlakte en is gereed om na vore te tree' (Boshoff 1979: 26). Tereg sê Dreyer (1983: 49): 'Die meeste godsienste is geneig om sowel universalistiese as eksklusiewe trekke te openbaar.'

Van die vroegste jare al het onderlinge vyande selfs saamgestaan in die aangesig van 'n groter gemeenskaplike vyand. Desiderius Erasmus haal die raad van die heidense filosoof Plutarchus (45-120 $\mathrm{nC}$ ) aan na aanleiding van die strydende burgers van die eiland Kreta. Sodra die Kretensers berig gekry het van ' $n$ gemeenskaplike vyand in aantog op see het hulle hulle onderlinge strydbyle op die eilandjie begrawe, hulle rusies gestaak en hulle kragte saamgesnoer - sin-kretisme (Boshoff 1979: 6). 
Een van die grootste dryfuere vandag is seker die mens se vrees van 'n totale aardse uitwissing. Behalwe die volkome sekulêre gedagte dat die mens vanuit die verskeidenheid van sy godsdienstige en ander geestelike en menslike samelewingskomponente tot 'n mondige selfversorgende wese kan ontwikkel, is die vrees in hierdie atoom-eeu vir 'n massale uitwissing, die dryfveer tot sinkretisme.

Japan bied vandag 'n mooi voorbeeld van wat met sinkretisme bereik kan word. Dit is 'n sinkretistiese verdraagsaamheid van verskillende godsdienste wat gebaseer is op sterk godsdienste as verskillende fondamentklippe van 'n hoëre struktuur - naamlik die sosiale. Die premier, Nakasone, het onlangs gesê dat hierdie Japanese openheid van gees 'n goeie uitvoerproduk kan wees na lande waar daar soveel konflik vanweë monoteïstiese benaderings is. 'n Voorbeeld van hoe die godsdienste deur die sogenaamde hoëre sosiale werklikheid gebruik kan word, is: 'n seënseremonie in die Sintoeheiligdom, trouseremonie in die Christelike kerk en die begrafnis in 'n Boeddhatempel (Van der Westhuizen 1988). In verband met die ontmoeting van wêreldgodsdienste moet die klem volgens die ekumenisme dan ook nie meer op bekering of verandering van geloof wees nie maar op dialoog. 'Ook die Japanese teologie laat blyk dat die Logos Spermatikos een van die veronderstellings is vir 'n ekumeniese teologie' (Van Wyk 1973: 104).

Die sosiale behoeftes van die mens vereis dikwels 'n eenvoudige, aanvaarbare, gelooflose gemeenskaplike religieusiteit. 'So het Rosseau 'n eenvoudige godsdiens van eerbied vir God en liefde vir die mensdom gepropageer. Wanneer die Wêreldparlement van Godsdienste in 1893 in Chicago gehou word, word uiteindelik ook hierby uitgekom' (Dreyer (1983: 63). Dreyer (1983: 66) toon dan duidelik aan dat ook die Vrymesselary presies dieselfde standpunt handhaaf. En hierop kan die universalisme soos onkruid op kompos tier.

Hierdie gees gedra ook deur die Vrymesselary het reeds in ons geskiedenis, soos ook vandag, groot invloed uitgeoefen:

Beïnvloed deur die Vrymesselary het die liberale predikante (van die Kaap in die vorige eeu) doelbewus daarna gestreef om die godsdienstige verskille uit te wis en tot éen praktiese Christendom te kom. 'n Predikant van die Kaapse kerk het byvoorbeeld na die Boeddhisme, Mohammedanisme en 'al de andere godsdiensten' as 'splinters van de rots Jesus' verwys (Jordaan 1988: 21).

Waar sinkretisme slaag om die Christendom vir sosiale redes te akkommodeer, is die Christendom van sy ewigheidspenwortel, die Christelike geloof, ontneem. 


\section{EKUMENISME}

Juis op die terrein van die moderne ekumenisme groei die godsdienstige, sosiale en politieke universalisme op sy weligste ooit. Uit die geskiedenis van die begrip sinkretisme sê Boshoff (1979: 60) tereg: 'Hieruit lei mens af dat Ekumene en Sinkretisme ten nouste met mekaar verbonde is, want as jy aan Ekumene 'n bepaalde inhoud gee, word jy 'n ondersteuner van Sinkretisme.'

Ons gaan nie hier op die betekenis van die woord ekumene in die Nuwe Testament verder in nie (vgl daarvoor Sauerzapf 1975: 210). Hier is net van belang wat onder die begrip ekumenisme vandag in universalistiese sin bedoel word. Die oorsprong van die woord in die kerklike taalgebruik, moet waarskynlik na Martin Luther toe teruggevoer word. Hy het nie van die woord 'katoliek' gehou nie. Dit het vir hom die Roomse assosiasie van hiërargie gehad. 'Dit is moontlik hy wat die eerste die belydenisse van Nicea - Konstantinopel, Athanasius en die Twaalf Artikels ekumeniese belydenisse genoem het' (Boshoff 1979: 49).

In die besonder gaan dit vir die onderhawige om onder die begrip ekumenisme 'n gesekulariseerde godsdienstige universalisme te onderskei. 'Als Ziel und Leitbild aller ökumenischen Bemühungen gilt es, die "Einheit der Menschheit" zu verwirklichen (Sauerzapf 1975: 186). Waar eenheid 'n god geword het, dit wil sê meer aansien as waarheid geniet, daar word kerkeenheid maar ook wêreldeenheid 'Christelike eenheid in die wêreld' genoem (Labuschagne 1987: 381).

Hierbo is dit 'n gesekulariseerde godsdienstige universalisme genoem omdat dit inderdaad, soos Emil Brunner se leerling Peter Vogelsanger, gesê het, is, naamlik dat die ekumeniese beweging die Judaskus van die Christendom is waarmee die evangelie aan die wêreld verraai word (Sauerzapf 1975: 208).

Indien godsdienstig twee dinge aanvaar word, is die twee swaaideure oop na 'n universalistiese lewens- en wêreldbeskouing. Eerstens is die ewigheidstoekoms van mense. Indien daar godsdienstige gronde aanvaar word waarop 'n universalistiese ewigheid, dit wil sê 'n alomvattende ewige redding vir alle mense, gebaseer kan word, word dit 'n reflektiewe invloed op die gemeenskapslewe. Tweedens is 'n gesekulariseerde godsdiens. Dit is 'n mensgerigte of humanistiese wêreldgeoriënteerde instrument. Selfgemaakte ideologieë, waar universalisme as lewens- en wêreldbeskouing die veiligste en maklikste is, word dan godsdienstig gerealiseer.

Juis in hierdie verband vind ' $n$ mens in die ekumeniese literatuur dikwels die mening dat die Gees van God nie net in die kerk werk nie, maar ook in die kultuur, die letterkunde, die filosofie, die wetenskap, die politiek en so meer (Van der Westhuizen 1988). Die Gees van God sou dan geen onderskeid maak nie omdat die genade van God nie tot die kerk beperk is nie (Van der Westhuizen 1983: 39). Teen so 'n agtergrond kan 'n mens 'n uitspraak van Berkhof (1973: 554) verstaan: 
Die duisternis van verwerping en godverlatenheid kan en mag niet weggeredeneerd worden, maar kan evinmin vereeuwigd worden. In Gods naam hopen wij, dat de hel een louteringsweg zal zijn'.

\section{DIE NUWE}

Die ontwikkelende mens wat rasioneel in wetenskap en tegniek ontwaak en groei word 'n nuut- gerigte mens. Dit is 'n algemene waarheid soos histories te bemerk in die Aufklärung, die Rasionalisme en in die politieke praktyk van die Franse Revolusie (Labuschagne 1987: $495 \mathrm{wv}$ ). Hy rig op die nuwe. Hierdie mens van ons eeu vind maklik aanklank by die beloftes van die nuwe waaraan die ekumenisme en universalisme 'n voorkeur het. Begrippe soos new movement, new nation, new age, new humanity, new republic, new world, one world, nuwe strukture, nuwe sosiale orde en so meer, speel 'n sentrale rol in die nuwe universalisme van ons tyd. Omdat wetenskap en tegniek vandag die wêreld klein gemaak het (vliegtuig, ruimtetuie, radio, televisie), het 'die wêreld in alle opsigte een geword' (Scholtz 1962: 524). Dit het selfs so 'n verregaande gevolg dat die mediese wetenskap en selfs die bestaan van die mens ten opsigte van die gevaar van VIGS voor kritieke deure te staan kom. 'Die universalisme van die huidige beskawing het wêreldwye vermenging ingelei, veral op seksuele gebied .... Hierdie praktyk was nie voorsien deur die natuur nie, wat hom inteendeel toespits op spesie-vorming, dit wil sê toenemende differensiasie van en verwydering tussen groepe' (Die Afrikaner, bl 9).

Daar is ook diegene wat wil bewys dat die Illuminati wat op 1 Mei (die latere werkersdag, selfs sint Josefsdag genoem) 1776 opgerig is, agter al die kwaad van alle revolusies, oorloë en so meer sit. En dat die doel 'n Sataniese wêrelddiktatorskap is (Klapwijk 1988: 84-86). Uit die aard van die bose in die mens kan die kwaad in die volkewêreld natuurlik nie so monisties verklaar word nie. Die basis van die verlange na die nuwe is een of ander gelukstaat, utopie of ideale gemeenskap. Prof Van Zyl (1960: 67), aan wie hierdie artikel opgedra is, het nege-en-twintig jaar gelede in die klas gedikteer:

Amerika se kerke se opvatting van sending is dat dit die Christelike poging is om die hele wêreld te verander in 'n aardse koninkryk van geregtigheid. Sending is hier dieselfde as die realisering van die koninkryk van God in hierdie wêreld wat daarin bestaan dat die hele sosiale en politieke orde in hierdie wêreld verchristelik moet word. Alle magte van 'goodwill' moet gemobiliseer word vir die daarstelling van 'n nuwe wêreldorde waarin geen oorlogpongelykheid, rassevoor- 
oordeel, despotisme ensovoorts meer gevind sal word nie maar alleen geregtigheid. Nie-Christelike godsdienste is al meer beskou as potensiële of werklike bondgenote in hierdie grootste onderneming en nie meer as lewensgebiede buite Christus en sy openbaring wat tot onderwerping aan Hom gebring moet word nie.

Hierdie benadering dat alle godsdienste sinkretisties moet saamwerk tot 'n hoère doel as die godsdiens self, naamlik die realisering van 'n nuwe sosiale orde, dra nie by tot die ware verinheemsing van die Christelike geloof in 'n bepaalde volk nie: 'Die sinkretistiese resultaat is dat $60 \%$ van Zimbabwe se Christene met een voet in die Tradisionele Godsdiens van Afrika staan, terwyl die ander voet in die Christendom staan' (Van der Westhuizen 1988).

Die voorbeeld van Zimbabwe word hier genoem omdat die South African Council of Churches na Zimbabwe verwys in die konteks van 'n nuwe sosiale orde vir Suid-Afrika: 'Dit is veelseggend dat Zimbabwe gesien word as die voorbeeld van 'n nuwe sosiale orde' (Naudé 1983: 151). By die identifisering van sendingterreine is dit dus belangrik om die kwaliteit van Christenskap in ernstige oorweging te neem. 'Studies in Bophuthatswana het aan die lig gebring dat goed die helfte van die meer as $90 \%$ van die Tswanas wat sê dat hulle kerklidmate is inderdaad nie alleen geen belydende lidmate is nie, maar slegs 'n bepaalde affiniteit vir 'n bepaalde kerk het' (Kritzinger 1988: 283). Dit is omtrent soos die affiniteit tot rugbyspanne. My een seun is 'n Vrystater, die ander 'n Transvaler, ek 'n Noord-Transvaler.

Dit is merkwaardig hoe die klassieke of ongekerstende benadering van die Godsdienswetenskap die voorloper was van die moderne 'nuwe' benadering van die godsdienste. Die klassieke of rasionele Godsdienswetenskap sien al die godsdienste in piramidale of klimmende orde. Verder is die godsdienste laer af soos 'n blombedding waaruit die heuningby van die moderne of mondige mens die heuning van 'n volmaakte godsdiens kan produseer. Eintlik lê die ware godsdiens in sy nektar-fase reeds in alle godsdienste. Die mense van alle godsdienste is eintlik almal Christene - hoewel nog dormerend, latent, incognito en anoniem.

Die nuwe benadering van godsdienste is ook dat die goeie sosiale nektar uit elke godsdiens ge-ekstraheer moet word sodat die waarheid van godsdienste die nuwe sosiale orde kan onderbou.

Die 'New age Movement' kan 'n simbool word van konsekwente sinkretisme. Tereg sê Internos, wat reeds elders ook aangehaal is (Van der Westhuizen 1988): 'Die New age Movement wil alle godsdienste verenig en het plek vir almal, behalwe vir Jesus Christus.' 
In verband met Fritjof Capra se beskrywing van die lewens- en wêreldbeskouing van die 'New Age', sê prof Gerald Eberlein (Eberlein 1988):

Interessant ist Capras Bemerkung, New Age sei eine neue Utopie, 'auch hier dem Marxismus ähnlich'. Bei tiefergehender Analyse liesse sich zeigen, dass New Age durchaus keine neue, sondern in wesenlichen Punkten eine sehr alte Utopie ist, die Merkmale einer synkretistischen Ersatzreligion trägt.

Die nuwe slaan op elke lewensterrein uit, maar die nuwe politiek en die nuwe onderwys is veral noú met mekaar verbonde. Oop kerke, oop skole, oop kulturele liggame, oop klubs en so meer word alles gebruik om 'n universalistiese oop toekoms van veronderstelde vrede, voorspoed en vooruitgang te bewerkstellig. 'Die idee van oop skole is dan bedoel om die koms van hierdie 'globalistiese' bestel te bevorder en te verhaas' (Pienaar, Basson \& Strauss 1987: 11).

\section{DIE NUWE EN TEOLOGIE}

Om verskeie redes waarna in die loop van hierdie artikel reeds verwys is, vind die algemene gedagte van die nuwe sterk aanklank by 'n teologie van universalisme. Runia (1978: 86) sê:

Herhaaldelijk komt men uitspraken tegen dat Jezus Christus voor allen gestorven is. Men spreekt de laatste jaren graag over de 'new humanity' (niet alleen in ze zin van het nieuwe mens-zijn, maar ook van de nuwe mensheid). Men legt verbanden tussen de eenheid van de kerk en de eenheid van de wereld en spreekt zeer plerofoor over het laaste .... De Geest van God maakt geen onderscheid. De genade van God is niet beperkt tot de kerk .... Dit alles is ook geen wonder als men ziet hoezeer universalistiche tendenzen in de nieuwere teologische ontwikkelingen aanwezig zijn.

In hierdie kringe van 'n teologiese universalisme kom die begrip van 'n kosmiese Christus ook dikwels voor: 'In onze tijd hebben verschillende theologen deze gedachte (van bijv Col 1 en Ef 1) uitgewerkt in de vorm van de 'kosmische' Christus, die 'aanwezig is in alle ontwikkelingen van de geschiedenis, in alle revolutionaire bewegingen van de maatschappij en in al de ideeën en strevingen der religies' (Runia 1978: 83). 
Die teologiese onderbou van hierdie oppervlakkige gemeenskapsuniversalisme, gaan baie beslis nie terug op die gereformeerde siening van die kruisteologie nie, maar op ' $n$ inkarnasieteologie. Nie Augustinus nie maar Origines is in die ekumeniese teologie aan die woord (Zuidema 1965: 118). Nie Calvyn nie maar Irenaeus is aan die woord. In die Niceense Belydenis word bely dat ons glo in 'Jesus Christus ... wat ter wille van ons, die mense, en ter wille van ons saligheid ... mens geword het ....' Die kruisteologie interpreteer die 'ter wille van ons saligheid' as verklarend vir die menswording van Christus 'ter wille van ons, die mense'. Die inkarnasieteoloog interpreteer dit as bykomende rede vir die menswording van Christus. Christus sou dus mens geword het ook al was daar geen sondeval nie! Die menswording word as skakel in die ontwikkelingsketting van die universele mensheid gesien. Dit is hierdie gedagte wat J Sittler op New Delhi weer skerp vertolk het en sedertdien navolging en uitbouing vind in die ekumenisme - selfs deur H Berkhof (Versteeg et al 1978: 90).

Tereg word die lesing van J Sittler (1962) deur J du Preez (1988b: 69-78) soos volg getipeer: 'The point of view propounded by J Sittler in his paper "Called to unity" at the New Delhi conference of the World Council of Churches in 1961, in which he, on account of a passage such as Col 1: 15-20, speaks of the cosmic Christ present in all religions of the world' (Du Preez 1988b: 77).

Hierdie gedagte word volgens 'n Ou Testamintikus ook in die Ou Testament gevind. Daarby sê hy (Loader 1985: 14): 'The value of the Old Testament as the evidence of Israelite religion is that it provides us with a corrective on the New Testament.' Teen hierdie agtergrond kan onder andere die volgende stellings verstaan word:

On the other hand his goodness also demands that he forgives the sinner and saves him from the destruction of punishment, and so God is also a God of love whose love demands a universal salvation ...' (Loader 1985: 29).

The one God can be known in more than one religion, and the salva. tion of people does not depend on their religion. These are the correctives of the Old Testament on the New. Conversely, the correctives of the New Testament on the Old are that there in fact is such a thing as salvation into God's eternity, and that Christ is the way in which his love has achieved this. So all men and women are saved irrespective of their religion (Loader 1985: 30). 
Van hierdie universalisme gebou op die mening dat die Ou Testament 'n korrektief op die Nuwe is, sê 'n ander Ou Testamentikus in Noorweë: 'Prinsloo also criticises Loader for using Old Testament texts somewhat eclectically. This criticism is understandable since Loader has avoided all texts that adopt a critical attitude towards other religion' (Holter 1988: 8). Die teregwysing en riglyn van Holter klink behartenswaardig:

Loader's purposely provocative statement that the Old Testament must be allowed to correct the New seems to be a kind of modern antithesis to Marcion's rejection of the Old Testament. Both views are to be rejected. The Old Testament must be used - but in a Christian way' (Holter 1988: 9).

\section{NUWE TEOLOGIE}

Die universalisme en die sosiale gerigtheid van die nuwe teologie wat met sy inkarnasieteologiese agtergrond in die ekumenisme opereer, kom baie duidelik ook in die politieke konteks van Suid-Afrika na vore. Prof AD Pont haal die nuwe geloofsbelydenis aan (Pont 1988: 11) wat in 1988 deur die Wêreldraad van Kerke 'vir 'n wêreldgebedsdag ten behoewe van Swapo-Namibië' opgestel is:

Ek glo aan 'n kleurblinde God, Skepper van technicolor-mense, wat die heelal geskep het en voldoende grondstowwe gegee het sodat dit regverdig onder alle mense verdeel kan word. Ek glo aan Jesus Christus wat uit 'n eenvoudige vrou gebore is wat gehoon, aangerand en tereggestel is, en wat op die derde dag opgestaan het en teruggeveg het. Hy het die hoogste raadsale van mense bestorm waar $\mathrm{Hy}$ die yster heerskappy van ongeregtigheid vernietig het. Van nou af sal $\mathrm{Hy}$ voortgaan om oor die haat en hoogmoed van mense te oordeel.

Ek glo aan die gees van versoening, die verenigde liggaam van verontregtes, die gemeenskap van die lydende massas, en die krag wat die mens-onterende magte oorwin. Ek glo in die opstanding van die mens in geregtigheid en gelykheid, en die uiteindelike triomf van ware broeder-en susterlikheid.

Tendense van hierdie nuwe teologie, wat werklik nie meer teologie is nie, wat bou op die universalistiese humanisme van vryheid, gelyklteid en broederskap, en niks 
meer weet van die partikularisme van God, gesin en volk nie, kom onder die dryfkrag van die humanisme en onder die vlag van menseregte al meer tot openbaring in die Suid-Afrikaanse samelewing.

In hierdie verband moet 'n kort verwysing na die humanistiese Sosialisme in die algemeen en na die saak van menseregte gemaak word.

\section{SOSIALISME EN MENSEREGTE}

Dit is hier nie nodig om ook op die liberalisme en so meer en op die verskillende vorme van Sosialisme, Marixisme en Kommunisme in te gaan nie. Die basiese wal eie aan al hierdie kategorieë en hulle verskillende vorme is, is die universalistiese filosofie. Omdat alle mense voedselbehoefte, produksievermoë en arbeidsplig het, is almal gelyk en is almal eenders bestem. 'Dat die mens op die natuur aangewese is om te kan bestaan en dat hy, anders as diere, moet produseer om in sy behoeftes te kan voorsien, is vir Marx 'n deurslaggewende element in sy argument aangaande die universele sosiale aard van die mens' (Esterhuyse 1984: 116). Die werkersuniversalisme van die Sosialisme bied filosofies 'n geweldige aantrekkingskrag vir die religieuse mens. Die aard van genoemde universalisme is 'n vervangingsgodsdiens. Byna vir elke religieuse kategorie is daar 'n Marxistiese-Leninistiese substituut: Evangelie word vervang met die goeie boodskap vir verdruktes, eskatologie word vervang met 'n utopie, bekering word vervang met revolusie, lydende Verlosser word vervang met proletariaat, Satan word vervang met Kapitalisme, die twee bedelings hiernoumaals en hiernamaals word vervang met pre-revolusionêre en post-revolusionére bedelings, sonde met anti-sosialisme, skepping word vervang met produksie, kerk word vervang met kamerade en so meer. Die belangrikste is dat God vervang word met kollektiewe mensheid (vgl Du Preez 1988a: 35-49).

Die onontwykbaarheid en die onomkeerbaarheid van die geskiedenis wat sal uitloop op 'n universele wêreldkommunisme word in die filosofie van die Marxisme gedank aan wat genoem kan word die goddelike mag van die kollektiewe mensheid. Terwyl die mens, die individu, die partikularistiese die kern is waarom dit gaan, kan hy nie wat vir hom die beste sou wees teen die bringkrag van die universele kollektiewe mensheid in, verander nie.

Die kollektiewe mensheid funksioneer deur in troebel water nog te vis met skynbaar aanneemlike aas soos wêreldmening en menseregte.

Op die oog af klink menseregte goed: 'Elke mens se regte word deur sy medemens se regte beperk en bepaal. My naaste se reg is ook my plig en verantwoordelikheid. Op my eie werf kan ek my eiendomsreg, ten volle geniet; ek mag dit 
egter nie so misbruik dat ek my buurman se eiendomsreg misken nie. Dit is my plig om sy reg te erken' (Wiechers 1988: 141).

Indien 'n stelling soos hierbo egter grondig ontleed word, kom die universalisme wat daaraan ten grondslag le na vore. Waarop is die regte van my buurman, en van my, byvoorbeeld gebaseer? Hoe groot is my eie werf - net dít wat ek onlangs met my eie geld gekoop het, of ook dit wat my eie voorouers al 'n tyd gelede met hulle bloed gekoop het? Die grondslag en basis van menseregte is 'n universalisme en nie 'n partikularisme van die eiesoortige of nasionalisme nie.

Daar word gesê: 'Kerkleiers soek ootmoedig na die gemeenskaplike waardes wat menseregte onderle. Daarmee wil hulle praktiese betekenis aan hulle boodskap van versoening gee' (Wiechers 1988: 137). By nadere ontleding sou blyk dat die gemeenskaplike waardes en die praktiese betekenis van die boodskap van versoening in hierdie konteks van menseregte nie Bybels nie, maar universalisties gefundeer is.

Die VVO se Universele Verklaring van Menseregte in 1948 (Du Toit (red) 1984: 122-127) gaan reeds in artikel 1 van die universalistiese intimiteit van alle mense uit: 'Alle mense is vry gebore met ewe veel waardigheid en regte. Bedeeld met rede en gewete, behoort hul teenoor mekaar in 'n gees van broederlikheid op te tree.'

'n Regsgeleerde het duidelik aangetoon hoe die sogenaamde menseregte besig is om die standaard vir Christelikheid in 'n land soos die Republiek van SuidAfrika te word (Potgieter 1988: 1-42). Feitlik op elke kerklike terrein begin hierdie vereenselwiging van menslikheid en Christelikheid uitslaan. Potgieter (1988) verwys na vele daarvan. ' $n$ Bykomende voorbeeld is dié van die wèreldbekende Roomse teoloog Hans Küng wat '... in a recent lecture in Cape Town, made much of the humanum ('respect for human dignity and fundamental values') as a general-ethical criterion for authentic religion' (Du Preex 1988b: 78).

Wanneer menseregte en Christelikheid sinonieme word, is die weg gebaan en hindernisvry oop tot ' $\mathrm{n}$ veronderstelde hoër religieusiteit van versoening, sinkretisme en universalisme op die sosiale dimensie van 'n land se bevolking. Die kerk in sy veelstaltigheid word teen hierdie agtergrond maklik sektariese denominasies genoem wat nie bevorderlik is vir die eenheid van die mensheid nie. SS Maimela sê byvoorbeeld:

... the fact that no single denomination has the final word on God, because each one of them is culturally, socially, politically and historically conditioned in its perception of the truth, should encourage churches not to look with pride to their sectarian creeds .... 
Should Christians and churches begin to move in that direction then, I believe, there is hope for the unity of both the church and humanity in Christ, who alone is the source of reconciliation (Vorster 1982: 10).

Hierdie tendens is waarneembaar in die verslag wat die Raad vir Geesteswetenskaplike Navorsing oor godsdiens, tussengroepverhoudinge en sosiale verandering in Suid-Afrika gepubliseer het (Marais 1985). Kritici het reeds die aandag daarop gevestig dat 'n sosialistiese politieke teologie met universalistiese inslag 'n tendens in die vloeirigting van hierdie verslag vorm (Van der Westhuizen 1986b). Na aanleiding van hierdie verslag sê prof PJ van der Merwe (Van der Merwe 1986: 574):

Baie mense wat tans om 'n unitere staat en samelewing pleit, het klaarblyklik self nie 'n duidelike nasionale toekomspersepsie nie .... Identiteitspannings wat tans latent is, gaan dan na vore kom en die eindresultaat sal waarskynlik 'n gemeenskap wees wat weer eens uit verskillende groepe saamgestel is, sy dit dan langs ander lyne en met ander grense ....

\section{VERHOUDING}

Dit is nie nodig om hier partikularisme in die godsdienstige en politieke wêreld van vandag op sigself staande te ontleed nie. Eerstens omdat dit teenoor universalisme 'n afgaande plek inneem. Tweedens omdat dit as vyandige objek van universalisme noodwendig reeds aan die beurt gekom het. Derdens omdat dit sáám met universalisme eers werklik gewaardeer kan word in die korrekte verhouding wat dit tot mekaar het.

Vir die Skrifgebonde gelowige in Christus wat die enigste weg, waarheid en die lewe is, sonder Wie niemand na die Vader toe kom nie (Joh 14:6), kan die saak van die uitverkiesing nie vir 'n humanistiese universalisme laat vaar word nie (vgl Van der Westhuizen 1982: 211-224). Die erkenning van die bestaansreg van die verskeidenheid ook in die mensewèreld, van byvoorbeeld volke, tale, kulture, nasionalismes, word ook deur die Nederduitsch Hervormde Kerk se volkskerkbeskouing gehandhaaf. Hieroor het daar 'n publikasie vanweë die Kerk verskyn (Botha, Van der Westhuizen \& Van Zyl 1989 ter perse). Prof Van Zyl, aan wie hierdie artikel opgedra is, het reeds in 1961 in sy klasdiktaat oor die volkskerk onder andere gesê: 
'n Volkskerk in die sin van 'n ko-eksistensie van kerk en volk moet dan ook afgewys word. Maar dit beteken nie sonder meer dat daarmee die hele volkskerk gedagte prysgegee moet word nie. Ons dink in hierdie verband aan die opvatting van Hoedemaker wat ' $n$ volkskerk sien as daardie kerk wat ' $n$ verantwoordelikheid het teenoor die hele volk. Hierdie voorstelling van die volkskerk wortel in die Reformasie. Rome ken nie so 'n begrip nie (Van Zyl 1961: 99).

Die eensydige keuse net vir die bestaan van ' $n$ volk of 'n groep volke, 'n kerk of 'n groep kerke, 'n mens of 'n groep mense is 'n partikularisme wat vyandig staan teenoor universalisme; dit is 'n partikularisme wat ook nie in die lig van die Bybelse boodskap plek moet hê nie. Die eensydige keuse net vir die verlossing van alle mense, elke mens kop vir kop, en die gelykheid van alle menslike funksies en produkte, is 'n universalisme wat vyandig staan teenoor enige vorm van partikularisme: dit is 'n universalisme wat ook nie in die lig van die Bybelse boodskap plek het nie.

Net soos die korrekte verhouding tussen kerk en wêreld nie met die voorsetsels teen, onder, bo, langs, buite en van beskryf kan word nie, maar met die voorsetsel in - die kerk in die wêreld - net so is die korrekte verhouding van partikularisme en universalisme te vind in die verhouding waar die evangeliese partikularisme in die mensdomlike universalisties tereg kom. Die saad van die Woord van God wat die kerk van Christus in 'n volksdeel inbring, is die saad en groeisel waarin daardie volksgeheel ewig behoue bly.

Die gedagtes ten grondslag van Jesaja 6: 13; Romeine 11: 26; Matteus 24: 14; Openbaring 7: 9 en 21: 3, 26 en andere, dui daarop dat ons moet onderskei tussen 'n verkeerde en 'n korrekte universalisme as lewens- en wêreldbeskouing. Daar is 'n kwantitatiewe en 'n kwalitatiewe universalisme; 'n alheid- en 'n volheiduniversalisme. Die volheid van Israel word gered, die volheid van elke volk, die volheid van die mensdom, die volheid van die mens, die volheid van die skepping. Hoe dit daar gaan uitsien is nog nie openbaar nie. Maar ons leef in die lig van wat reeds geopenbaar is.

\section{Literatuurverwysings}

BERKHOF, H 1973. Christelijk geloof. 2de druk. Nijkerk: Callenbach.

BOTHA, SJ, VAN DER WESTHUIZEN, HG \& VAN ZYL, FJ [1989]. Onder red van SJ Botha. Belydende volkskerk. Pretoria: Kital.

BOSHOFF, PJ 1979. Sinkretisme in die ekumene van die twintigste eeu. DDproefskrif, Universiteit van Pretoria.

DIE AFRIKANER. Vigs: Gaan dit die mensdom uitdun of uitwis? 30 Maart 1988, bl 9. 
DREYER, TFJ 1983. Vrymesselary as groep in, naas en teenoor die kerk. DDproefskrif, Universiteit van Pretoria.

DU PREEZ, J 1988a. Die aantrekkingskrag van die Marxisme vir die Derde Wêreld. Kaapstad: NG Kerk. (Stellenbosse Teologiese Studies 16.)

DU PREEZ, J 1988b. John Calvin's contribution to a theologia religionum. Missionalia 16/2, 69-78.

DU TOIT, DA (red) 1984. Menseregte. Kaapstad: Tafelberg.

EBERLEIN, GL 1988. Synkretistische Ersatzreligion? Evangelische Kommentare Januar, 41-43.

ESTERHUYSE, WP 1984. Karl Marx filosoof van die revolusie. Kaapstad: Tafelberg.

EYBERS, IH, KöNIG, A \& STOOP, JH 1978. Inleiding in die Teologie. Pretoria: NG Kerkboekhandel.

GETROUW, s a . Wereldregering door transcendente Meditatie. Maandblad van de Intemationale Raad van Christelijke Kerken 32/2, 860-862.

HAT 1979. Verklarende Handwoordeboek van die Afrikaanse Taal. sv partikularisme, sv universalisme. Johannesburg: Perskor.

HOLTER, K 1988. Missiology and the Old Testament Theology of Religions. Missionalia 16/1, 4-12.

JORDAAN, GJC 1988. Die oorsake van die stryd. Bybel en Volk 3/4, 15-30.

KLAPWIJK, H 1988. Toe die mense slaap .... Somerset-Wes.

KRITZINGER, JJ 1988. Die gemeentelike bediening in die lig van die sendingnood in Suid-Afrika. NGTT 29/3, 280-288.

LABUSCHAGNE, JP 1987. Die historiese konteks van 20ste eeuse samelewingsteologieë. DD-proefskrif, Universiteit van Pretoria.

LOADER, JA 1985. 'Theologia Religionum' from the perspective of Israelite religion - an argument. Missionalia 13/3, 14-32.

MARAIS, HC, OOSTHUIZEN, GC, COETZEE, JH, DE GRUCHY, JW, HOFMEYER, JH \& LATEGAN, BC 1985. Religion, intergroup relations and social change in South Africa. Director HC Marais. Pretoria: HSRC.

MEREDITH, RC 1986. Is God trying to save the world now? USA Worldwide Church of God.

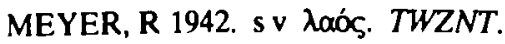

NAUDe, RM 1983. Die etiek van die ekumene toegespits op die South African Council of Churches. DD-proefskrif, Universiteit van Pretoria.

PIENAAR, JJ, BASSON, JL \& STRAUSS, FJ 1987. Oop skole - gaan ons dit toelaat? Windhoek: Eros Uitgewers. 
PONT, AD 1988. Die 'nuwe teologie' en die stryd van die Afrikaner vandag.

Die Afrikaner, 10 Augustus 1988, 4 \& 11.

POTGIETER, JM 1988. Gedagtes oor die Christelike grondslag van menseregte.

Intreerede, Departement Privaatreg, Universiteit van Suid-Afrika.

RUNIA, K 1978. De Wereldraad in Discussie. Kampen: Kok.

SAUERZAPF, R 1975. Die Săkularisierung der Genfor Ökumene. DD-proefskrif, Universiteit van Pretoria.

SCHOLTZ, GD 1962. Die stryd om die wêreld. Voortrekkerpers.

SITTLER, J 1962. Called to unity. Ecumenical Review 14 Jan, 177-187.

VAN DER MERWE, PJ 1986. RGN-Verslag oor godsdiens, tussengroepverhoudinge en maatskaplike verandering in Suid-Afrika. HTS 42, 564 579.

VAN GENDEREN, J 1961. s v universalisme. Christelijke Encyclopedie.

VAN DER WESTHUIZEN, HG 1982. Uitverkiesing en sending as instrument. Die kerk in die wêreld - ' $n$ bundel opstelle. Pretoria: HAUM.

VAN DER WESTHUIZEN, HG 1983. Ekumene - Marx of Markus? Pretoria: Kital.

VAN DER WESTHUIZEN, HG 1984. Blankheid en saligheid. Pretoria: Kital.

VAN DER WESTHUIZEN, HG 1986a. Nou en ewig. Pretoria: Kital.

VAN DER WESTHUIZEN, HG 1986b. Sosialistiese teologie ontmasker. Leer- en Lewenskwessies in Suid-Afrika 10/2, 7-23.

VAN DER WESTHUIZEN, HG 1988. Verinheemsing en sinkretisme, Die Hervormer, Oktober 1988, 9.

VAN DER WESTHUIZEN, HG (red) 1989. Blankheid en waarheid. Pretoria: Kital.

VAN WYK, DJC 1973. Die probleem van die algemene openbaring, histories nagegaan en prinsipieel getoets. DD-proefskrif, Universiteit van Pretoria.

VAN ZYL, FJ 1960. Klasnotas in Sendingwetenskap, Universiteit van Pretoria.

VAN ZYL, FJ 1961. Klasnotas in Sendingwetenskap, Universiteit van Pretoria.

VERSTEEG, JP, GRAAFLAND, C, TUKKER, CA, VAN'T VELD, H, TIGGHELAAR, JJ, FAHNER, C, BOUT, CG, MOENS IA \& VAN HEEST, W 1978. Gij die eerstijds verre waart .... Utrecht: De Banier.

VORSTER, WS (ed) 1982. Denominationalism - its sources and implications. Pretoria: University of South Africa.

WIECHERS, M 1988. ' $n$ Politieke idiotikon vir Suid-Afrika. Kaapstad: Tafelberg. ZUIDEMA, SU 1965. De Christus der Schriften en Oecumenische Theologie. Amsterdam: Buijten en Schipperheijn. 